\title{
Urgensi Pendidikan Inklusif: Studi Kasus pada Kegiatan B'Religi di SMA Negeri 3 Malang
}

\author{
Faridi \\ Universitas Muhammadiyah Malang, Indonesia \\ faridi_umm@umm.ac.id
}

\begin{abstract}
This article wants to examine the importance of inclusive education for students in SMA Negeri 3 Malang. Through one of its religious activities entitled B'Religi, this school wants to teach its students about tolerance and respect for different groups. This is based on the plurality of the Indonesian nation. This research uses a qualitative approach with a single case study type. Data collection techniques are carried out through observation, interviews and documentation. Meanwhile, data analysis used a descriptiveexploratory model involving three components of analysis, namely: data reduction, data presentation, and conclusion drawing. This research paper concludes that the application of inclusive education cannot be done only in a conceptual level, namely formal learning in the classroom. Inculcating an inclusive attitude which means respecting different religious groups, for example, because in SMA 3 Malang there are several students from various religions, it is very important to be nurtured through refraction and modeling. Keywords: Inclusive Education; B'Religi; SMAN 3 Malang
\end{abstract}

Abstrak. Artikel ini ingin mengkaji tentang pentingnya pendidikan inklusif bagi peserta didik di SMA Negeri 3 Malang. Melalui salah satu kegiatan keagamaannya yang bertajuk B’Religi, sekolah ini ingin mengajarkan anak didiknya mengenai toleransi dan penghargaan terhadap kelompok berbeda. Hal ini didasari atas pluralitas bangsa Indonesia. Penelitian ini menggunakan pendekatan kualitatif dengan jenis studi kasus tunggal. Teknik pengumpulan data dilakukan melalui observasi, wawancara dan dokumentasi. Sementara itu, analisis data menggunakan model deskriptif-eksploratif dengan melibatkan tiga komponen analisis, yaitu: reduksi data, penyajian data, dan penarikan kesimpulan. Riset paper ini menyimpulkan bahwa penerapan pendidikan inklusif tidak bisa bila sekadar dilakukan dalam tatararan konseptual, yaitu pembelajaran formal di ruang kelas. Penanaman sikap inklusif yang berarti menghargai kelompok agama berbeda, misalnya, karena di SMA 3 Malang terdapat beberapa peserta didik dari agama yang beragam, sangatlah penting dibenihkan melalui pembiasan dan keteladanan.

Kata Kunci: Pendidikan Inklusif, B'Religi, SMAN 3 Malang

Copyright (C J-PAI: Jurnal Pendidikan Agama Islam. All Right Reserved.

This is an open-access article under the CC BY-SA license

(https://creativecommons.org/licenses/by-sa/4.0/).

Correspondence Address: jpai@uin-malang.ac.id 
Faridi Faridi: Urgensi Pendidikan Inklusif: Studi Kasus Pada....

\section{A. Pendahuluan}

Jamak diketahui bahwa Indonesia adalah negara yang kaya keberagaman. Tak hanya bahasa, tradisi, budaya, etnis, dan ras, tetapi juga agama. Jaminan atas pluralitas tersebut tertuang pada UUD 1945 Pasal 29 ayat 2 yang menjelaskan bahwa: "Negara menjamin kemerdekaan bagi tiap-tiap penduduk untuk memeluk agamanya masing-masing dan untuk beribadah menurut kepercayaanya". Pasal tersebut secara jelas memberikan jaminan perlindungan dan penghargaan terhadap beragam pemeluk agama untuk memeluk, meyakini dan menunaikan ibadah sesuai doktrin agamanya masing-masing.

Persoalannya, kemajemukan tersebut seringkali terusik oleh perilaku sejumlah pihak tertentu yang mengatasnamakan agama. Beberapa contohnya tampak pada Konflik MuslimKristen di Ambon (1999), pengusiran pemeluk Syiah di Sampang (2013), dan warga Ahmadiyah di Transito, Lombok cukup menjadi bukti bagaimana sebagian pihak menggunakan simbol agama untuk mempersekusi, mengusir dan memperlakukan secara kasar orang lain atas nama agama (Burhani, 2019). Akibatnya, doktrin agama yang sebenarnya mengajarkan kedamaian dan keselamatan, oleh sejumlah pemeluknya yang tidak bertanggungjawab diubah menjadi klaim kebenaran atas perkara tertentu sehingga menjadi salah satu faktor timbulnya konflik yang mengancam kesatuan dan persatuan NKRI (Bawazir, 2015).

Sejumlah konflik yang berlatarbelakang agama, ras, suku dan kelompok berbeda yang terjadi dalam beberapa tahun terakhir semakin mengkhawatirkan. Misalnya saja yang dilakukan Front Pembela Islam (FPI) atas tindakan persekusinya terhadap sejumlah orang yang dianggap memiliki pandangan keagamaan berbeda pada semester pertama 2017. menurut catatan Kathlean Azali, ada 59 aksi persekusi yang dilakukan FPI sepanjang Januari hingga Juli di tahun tersebut (Azali, 2017). Apalagi, perbincangan di media sosial yang bernadakan kebencian berbasis pelbagai perbedaan tersebut membuat situasi sosial semakin runyam. Penghargaan terhadap kelompok berbeda semakin tergerus sehingga mengancam disharmoni dalam kehidupan sosial (Lim, 2017).

Terlebih dalam sejumlah riset telah disebutkan mengenai lunturnya sikap inklusif masyarakat. Beberapa di antaranya, misalnya, hasil survei Setara Institute tentang persepsi peserta didik tingkat SMA di Jakarta dan Bandung yang menunjukkan bahwa satu dari 14 peserta didik ternyata setuju dengan gerakan Islamic State of Iraq and Suriah (ISIS). Begitupun dengan Maarif Institute yang menemukan fenomena sama. Pada 2015, Ma'arif melakukan riset sebanyak 98 peserta didik tingkat SMA. Dalam risetnya itu, Ma'arif menemukan sebanyak 40,82\% siswa yang menjawab bersedia, 8,16\% sangat bersedia untuk melakukan penyerangan terhadap orang atau kelompok yang dianggap menghina Islam. Sementara responden yang menjawab tidak bersedia mencapai $12,24 \%$ dan yang kurang bersedia sebanyak 25,51\%.

Begitupun di tingkatan mahasiswa, ada sejumlah organisasi keagamaan yang menjadi bibit dari pergerakan fundamentalisme Islam, seperti Harakah Tarbiyah, Hizbut Tahrir Indonesia (HTI) dan Jamaah Salafi, yang ide-ide pemikirannya bertentangan dengan prinsip nasionalisme dan dasar negara Pancasila (Nafi' Muthohirin, 2014) (Nafi Muthohirin, 2015). Padahal, di sejumlah negara maju, jika terjadi persoalan krusian terkait dengan cara berpikir yang bertentangan dengan ide-ide negara modern dan keutuhan sebuah negara, maka akan muncul pertanyaan mengenai dunia pendidikan kontemporer? Pertanyaan ini cenderung memberi beban berat terhadap lembaga pendidikan, seolah-olah menjadi institusi yang paling bertanggungjawab terhadap persoalan besar bangsa. Namun hal tersebut mengisyaratkan bahwa lembaga pendidikan memperoleh posisi dan fungsi yang sangat penting dalam kehidupan bernegara. Menurut Durkheim, lembaga pendidikan punya peran strategis dalam 
pengembangan sikap inklusif, karena merupakan satu-satunya lembaga yang mengumpulkan semua anak bangsa dalam waktu jangka panjang. Hal ini juga diungkapkan Mansurni Abadi dan Nafik Muthohirin dalam artikelnya bertajuk Metode Cultural Responsive Teaching dalam Pembelajaran Pendidikan Agama Islam (2020). Menurut keduanya, salah satu jalan keluar yang penting dan sistematis dalam mengupayakan terhapusnya tindak kekerasan berbasis SARA di masyarakat, adalah melalui strategi pendidikan, khususnya Pendidikan Agama Islam (Abadi \& Muthohirin, 2020).

Solusi untuk menemukan strategi terbaik pendidikan sikap inklusif bukan tidak diupayakan. Strategi mikro yang acapkali diterapkan berbentuk ekstrakurikuler semisal pramuka, peringatan hari-hari besar nasional atau peringatan hari-hari besar keagamaan, olah raga dan lain sebagainya adalah beberapa contohnya (Muaddab, 2020).

Menghindari cara-cara konvensional strategi pendidikan sikap inklusif tersebut, SMAN 3 Malang menyelenggarakan kegiatan Bhawikarsu Religi ( $B^{\prime}$ Religi), hal mana pada pelaksanaannya seluruh warga sekolah (pendidik, tenaga kependidikan, dan peserta didik) wajib mengikuti.

Berdasarkan paparan tersebut peneliti melakukan kajian lebih dalam seputar pendidikan dan pengajaran sikap inklusif di SMAN 3 Malang. Rumusan masalah yang diajukan adalah mengapa SMAN 3 Malang menyelenggarakan kegiatan $B^{\prime}$ Religi, dan bagaimana pelaksanaan pendidikan sikap inklusif pada kegiatan $B^{\prime}$ Religi tersebut.

Sikap inklusif dapat digambarkan sebagai perilaku sekumpulan orang yang menganut pandangan bahwa semua agama yang ada memiliki kebenaran dan memberikan manfaat serta keselamatan bagi penganutnya (Fernandes, 2018). Dengan demikian, Islam inklusif adalah cara pandang seseorang dalam berperilaku yang memberikan penghargaan terhadap pemeluk agama berbeda.

Sikap inklusif cenderung memandang positif perbedaan yang ada. Prinsip bersikap inklusif muncul karena adanya kebutuhan bekerjasama untuk mencapai cita-cita. Titik tolaknya adalah memandang sisi positif perbedaan dan mendorong usaha-usaha untuk mempelajari perbedaan, menarik sisi-sisi universal yang mungkin bernilai positif dan menunjang citacita/misi pembangunan masyarakat (A. Ghufron, 2010)(Nasional, 2010). Karena itu, dalam masyarakat inklusif siapapun dapat melakukan interaksi sosial dengan individu-individu yang memiliki keunikan dan perbedaan.

Masyarakat inklusif adalah masyarakat yang sangat menghargai kemajemukan (G. Ghufron, 2020). Mereka memandang semuanya sama seperti dirinya sendiri. Narasi-narasi "pengkafiran" pun tidak berkembang dalam paham ini. Maka dapat ditegaskan bahwa sikap inklusif merupakan sikap kemanusiaan universal. Kebalikan sikap inklusif adalah perilaku eksklusif, yaitu paham yang tidak mau menerima segala sesuatu yang datang dari luar golongan atau agamanya. Sikap eksklusif merupakan sikap menutup diri dari agama lain, atau pemahaman yang menganggap dirinya paling benar. Sikap eksklusif akan melahirkan pandangan bahwa ajaran yang paling benar hanyalah agama yang dipeluknya, sementara agama lain dianggap menyimpang.

Bhinneka Tunggal Ika adalah konsep lain dari inklusivisme. Demikian pula halnya dengan agama, bahwa tidak satupun agama yang mengajarkan kekerasan, mengajarkan rasa benci. Artinya inklusifitas dan toleransi kehidupan beragama telah ada di dalam ajaran agama.

Kajian tentang pendidikan sikap inklusif bukanlah topik baru. Ada banyak riset sebelumnya yang mengkaji tema yang sama. Penelitian Ahmad Fauzi (2017) berjudul Pendidikan Inklusif Berbasis Kearifan Lokal dalam Praktik Sosial di Ponpes Zainul Hasan Genggong Probolinggo, adalah salah satunya. Riset ini memaknai peran kiai terhadap nilai-nilai 
Faridi Faridi: Urgensi Pendidikan Inklusif: Studi Kasus Pada....

kearifan lokal Ponpes Zainul Hasan Genggong dalam membangun pendidikan inklusif. Hasil penelitian menunjukkan pendidikan Islam inklusif merupakan model pendidikan yang dibangun melalui nilai-nilai kearifan lokal (local wisdom) sebagai sistem sosial pesantren. Internalisasi nilai-nilai barakah tidak lepas dari peran dan tindakan sosial kiai melalui pemahaman dan penafsiran terhadap sumber primer yaitu al-Qur'an dan al-Hadits sebagai nilai utama dan keyakinan dasar. Model pendidikan Islam inklusif lebih banyak mengedepankan sikap saling menghormati, menghargai dan memelihara keselarasan hidup yang bertumpu pada nilai-nilai sosial.

\section{B. METODE}

Penelitian ini menggunakan pendekatan kualitatif dengan jenis penelitian studi kasus di SMAN 3 Malang. Teknik pengumpulan data dilakukan melalui observasi, wawancara dan dokumentasi. Wawancara digunakan untuk mengetahui padangan kepala sekolah, penggagas $B^{\prime}$ Religi, wakil ketua kurikulum, wakil ketua kesiswaan, pendidik (guru agama) tentang B'Religi sebagai strategi penanaman sikap inklusif. Obesrvasi digunakan untuk melihat aktivitas subyek yang mencerminkan penanaman sikap inklusif. Sedangkan dokumentasi digunakan untuk mengetahui berbagai dokumen kegiatan penanaman, pengembangan, dan pelaksanaan sikap inklusif. Teknik analisis data menggunakan model deskriptif-eksploratif dengan melibatkan tiga komponen analisis, yaitu: reduksi data, penyajian data, dan penarikan kesimpulan (John, 2014).

\section{HASIL DAN PEMBAHASAN}

Penting diketahui bahwa pendidikan inklusif merupakan bagian esensial yang menjadi tugas bagi sekolah (Muhaimin, 2005)(Syam, 2018). Selain dituntut meningkatkan pencapaian akademis, sekolah juga bertanggungjawab membentuk sikap inklusif peserta didik. Sebab itu, bagi SMA Negeri 3 Malang, penyelanggaraan kegiatan B'Religi, merupakan ijtihad menumbuhkan sikap inklusif. Kepala Sekolah SMA Negeri 3 Malang Wawan Pramunadi mengatakan bahwa kegiatan B'Religi adalah sebagai miniatur kehidupan bermasyarakat. Kegiatan ini mengajarkan urgensi komunikasi dan interaksi antar peserta didik yang berbeda keyakinan.

Tahapan kegiatan B'Religi yang diorientasikan pada penanaman sikap inklusif di SMAN 3 sejalan dengan prinsip pendidikan yang digagas UNESCO, bahwa pada tahap pertama pendidikan adalah "tahu", tahap kedua "mengerti", dan tahap ketiga mengerjakan yakni mengaplikasikannya, dan yang paling akhir bagaimana antar peserta didik bisa bekerjasama. Sebab itu, B'Religi merupakan sarana strategis bicara dari hati ke hati antar peserta didik. Mereka bisa berdialog secara leluasa.

Beberapa keuntungan yang didapat dari penerapan pembelajaran model B'Religi, antara lain (a) Kegiatan ini memberikan pengalaman nyata dalam berinteraksi dengan peserta didik yang berbeda secara keyakinan; (b) interaksi antar peserta didik yang berbeda agama mempermudah penanaman dan pemahaman pentingnya sikap inklusif; (c) peserta didik dapat mengaplikasikan pengetahuan dan keterampilan yang mereka pelajari dari pembelajaran formal mengenai nilai-nilai inklusif; (d) pendidik dapat melakukan refleksi sekaligus segera mengetahui efektifitas pembelajaran yang sudah berlangsung sehingga memberikan peluang untuk memunculkan gagasan baru guna menghindari kesalahan-kesalahan yang berkelanjutan.

Dalam hal ini, komitmen SMAN 3 Malang tidak hanya bertujuan untuk meningkatkan pencapaian akademis, tetapi melalui kegiatan ini juga pihak sekolah bertanggungjawab membentuk sikap inklusif peserta didik. Capaian akademik dan pembentukan sikap inklusif 
merupakan dua misi integral yang sama-sama mendapat perhatian. Dengan begitu, sekolah bisa menghasilkan lulusan yang diidealkan yang memiliki kecakapan akademik dan berkarakter yang bersumber dari nilai-nilai agama dan budaya bangsa, yakni lulusan yang mamiliki kecakapan personal dan kecakapan sosial.

Sebagaimana dijelaskan dalam Undang-Undang Sistem Pendidikan Nasional Tahun 2003 Pasal 1 bahwa tujuan pendidikan adalah mengembangkan potensi peserta didik untuk memiliki kecerdasan, kepribadian, dan akhlak mulia. Dengan demikian pendidikan tidak hanya membentuk insan Indonesia yang cerdas, tetapi juga berkepribadian sehingga melahirkan generasi bangsa yang tumbuh berkembang dengan karakter yang bernafaskan nilai-nilai luhur bangsa serta agama. Pembentukan sikap inklusif tidak akan terwujud jika hanya mengandalkan jam pelajaran pendidikan agama di ruang kelas yang hanya berlangsung tiga jam dalam satu pekan. Alternatifnya, SMAN 3 Malang membuat terobosan dengan menyelenggarakan berbagai kegiatan yang memuat pendidikan inklusif, salah satu aktifitas tersebut dinamakan $B^{\prime}$ Religi.

Choirulil Fatih, salah satu guru di SMA Negeri 3 Malang menjelaskan, $B^{\prime}$ Religi merupakan gagasan dari Kepala SMA Negeri 3 Malang Asri Widiaspari yang bertujuan meningkatkan kualitas pengetahuan keagamaan peserta didik, menjaga kesinambungan iman, sekaligus untuk menanamkan sikap inklusif peserta didik. Dengan kegiatan ini diharapkan internalisasi nilai-nilai ajaran agama yang terkait dengan sikap inklusif bisa tertanam kuat di hati peserta didik. Asri mengatakan, keyakinan agama peserta didik di SMAN 3 ini beragam. Melalui $B^{\prime}$ Religi setiap pagi ini, peserta didik diharapkan terbiasa mengingat Tuhan secara terus menerus dan menyadari kewajiban-kewajiban yang harus dikerjakan serta larangan-larangan yang harus dihindari, sekaligus memahami pentingnya menghormati keyakinan orang lain. Membentuk sikap inklusif pada peserta didik tidak bisa secara tiba-tiba. Sikap inklusif akan terbentuk melalui proses pembiasaan dan pembinaan terutama di lembaga pendidikan.

Salah satu kegiatan pada B'Religi adalah doa bersama sesuai dengan keyakinan masingmasing. Peserta didik yang beragama non muslim melakukannya di ruang keagamaan yang telah disediakan pihak sekolah. Kegiatan ini dilakukan oleh pendidik dan peserta didik yang beragama Kristen. Mereka berkumpul di ruang keagamaan, dipandu oleh pendidik yang juga beragama Kristen atau Katolik. Lalu, dilanjutkan dengan motivasi oleh pendidik yang bertugas sebagai pendamping/guru piket. Hal ini bertujuan agar peserta didik terus bersemangat dalam belajar, memberikan pemahaman tentang toleransi dan pentingnya menjaga kerukunan meskipun berbeda dalam berkeyakinan.

Sementara peserta didik yang beragama Islam melakukannya di kelas masing-masing. Rutinitas kegiatan do'a bersama ini merupakan salah satu bentuk pembinaan sikap inklusif kepada peserta didik. Do'a bersama ini bisa menumbuhkan sikap toleransi antar peserta didik dengan ragam agama berbeda. Kegiatan ini diawali dengan do'a dan dilanjutkan dengan bacaan Asmaul Husna, surat-surat pendek/Juz Amma, arti dan makna yang dikandungnya. Dilaksanakan pada Senin sampai Kamis mulai jam 06.45 WIB. Kegiatan ini dipandu oleh petugas Sesi Keagamaan Islam (SKI), yang terdiri dari peserta didik yang sudah terjadwal untuk memimpin kegiatan tersebut. Suara peserata didik yang bertugas terdengar di seluruh ruangan kelas melalui pengeras suara yang sudah tersedia, sementara peserta didik yang lain mengikutinya. Dilanjutkan dengan motivasi oleh pendidik yang bertugas sebagai pendamping/guru piket.

Selain melantumkan kalimat thayyibah (Asmaul Husna, dan ayat-ayat pendek/Juz Amma), juga diadakan kegiatan BTA (baca tulis al-Qur'an) yang dilaksanakan setiap Jum'at sebelum pembelajaran formal dimulai. Di samping baca tulis al-Qur'an juga diisi dengan meteri yang tidak diajarkan pada mata pelajaran agama di kalas, sehingga peserta didik terhindar dari kejenuhan. Kegiatan ini wajib diikuti oleh peserta didik yang beragama Islam sebagai penunjang 
Faridi Faridi: Urgensi Pendidikan Inklusif: Studi Kasus Pada....

pembelajaran yang terkait dengan materi keagamaan, seperti praktik shalat sunnah dan shala wajib, membaca al-Qur'an. Pada kegiatan ini peserta didik didampingai pendidik yang beragama Islam.

Kegiatan lain yang termasuk B'Religi untuk peserta didik beragama Kristen adalah PASKA (Persekutuan Penganut Kristen). Model kegiatan pada persekutuan ini berupa do'a bersama serta pujian-pujian rohani, serta penyampaian firman yang dipimpin oleh pendidik yang beragama Kristiani. Kegiatan ini diadakan untuk memperdalam spiritual keagamaan peserta didik non muslim, ditambah motivasi-motivasi yang berisikan kerukunan antar umat beragama. Muatan materi pada kegiatan ini tidak sama dengan pembelajaran formal (agama Kristen) di kelas. Para pengampu materi agama Kristen telah membuat kisi-kisi materi khusus untuk kegiatan PASKA. Penjadwalan yang dilakukan para pendidik sebagai pelayanan firman juga telah tersedia di mading ruang keagamaan (Protestan-Katolik).

Salah satu guru pembina keagamaan Choirulil Fatih menuturkan, pada pelaksanaan kegiatan belajar mengajar seperti yang saya laksanakan di kelas, peserta didik non muslim jarang ada yang keluar meskipun diberikan kebebasan untuk meninggalkan kelas. Mereka tetap mengikuti materi yang diberikan, meski materinya terkait dengan Tauhid. Kuncinya adalah tidak menyakiti perasaan mereka atau tidak mendiskriditkan pihak manapun.

Pengembangan sikap inklusif pada peserta didik menuntut pengampu mata pelajaran Pendidikan Agama Islam dan Budi Pekerti yang lebih mumpuni agar materi-materi yang diajarkannya memberi dampak positif bagi pembentukan sikap inklusif (Nurcholish, 2020)(Muaddab, 2020). SMAN 3 Malang adalah sekolah umum dan peserta didiknya mayoritas a beragama Islam. Dari penjelasan pengampu mata pelajaran PAI selama ini di SMAN 3 sama sekali belum pernah terjadi konflik, kerusuhan, bentrokan, tawuran, diskriminasi, dan lain sebagainya dengan mengatasnakan kepentingan agama. Ini berarti pada diri mereka tertanam jiwa toleransi yang tinggi terhadap pemeluk agama.

Sikap inklusif harus menjadi nilai yang termuat dalam pelajaran agama (Mahfud, 2006). Terlebih SMAN 3 merupakan sekolah umum yang berkewajiban menampung setiap peserta didik dari latar agama apapun, sehingga penanaman ideologi agama yang inklusif mutlak diberikan. Jadi setiap peserta didik harus didorong untuk bersikap toleran antara satu dengan yang lain. B' Religi merupakan salah satu sarana pembentukan sikan inklusif tersebut, karena pada waktu bersamaan semua peserta didik mempraktikan ajaran dan aktifitas kagamaannya masing-masing.

Menurut salah satu pendamping peserta didik Kriten Hartono, peserta didik di SMAN 3 adalah pilihan. Jadi mereka yang bersekolah di sini berarti sudah terseleksi secara ketat, baik dari sisi prestasi akademik maupun perilakunya. Sikap inklusif peserta didik, atau sikap toleran di SMA ini begitu menonjol, dapat dilihat dari kegiatan-kegiatan yang ada di sekolah maupun di luar sekolah. Peserta didik yang beragama Islam tidak pernah mendiskriminasi peserta didik yang non-muslim, begitu pula sebaliknya. Mereka saling mendukung, membantu dan tolong menolong tanpa melihat latar belakang agama yang dipeluknya.

Selain itu, kegiatan yang menumbuhkan sikap inklusif juga terjadi dalam berbagai kegiatan, misalnya saat buka puasa bersama di bulan Ramadan. Peserta didik non muslim sama sekali tidak minder terlibat di dalamanya. Mereka membantu menyiapkan berbagai keperluan buka puasa seperti menyajikan ta'jil. Demikian juga pada Idul Adha, anak-anak non mulim juga terlibat dalam pendisistribusian daging hewan kurban ke berbagai pelosok sebagaimana telah ditetapkan oleh panitia. Hal serupa juga dilakukan oleh peserta didik yang beragama Islam, ketika peserta didik yang beragama non-Islam ingin melaksanakan kegiatan peribadatan dan 
memerlukan tempat, maka peserta didik yang beragama Islam khususnya yang terkabung pada SKI ikut juga membantunya mempersiapkan berbagai kebutuhan.

$B^{\prime}$ Religi memberikan pengalaman autentik bagi peserata didik. Pada kegiatan ini peserta didik tidak hanya belajar agama sesuai keyakinan masing-masing, tapi juga belajar tanggung jawab individu dan kerjasama antar peserta didik yang berbeda agama agar menjaga kehidupan yang harmoni dan memahami perasaan peserta didik yang lain. Choirul Fatih mengatakan, kerukunan dan kedamaian di masyarakat sulit terwujud jika kesadaran masyarakat terhadap pentingnya sikap inklusif masih rendah. Untuk mewujudkannya diperlukan pembiasaan sejak dini tepatnya sejak dari bangku lembaga pendidikan.

$B^{\prime}$ Religi, sebagai salah satu strategi menumbuhkan sikap inklusif diharapkan mampu menghasilkan peserta didik yang dapat memelihara keimanan baik secara ideal maupun aktual. Secara ideal, B'Religi diharapkan mencetak generasi bangsa yang beriman, dan bertakwa. Adapun secara aktual diharapkan mencetak generasi muda yang dapat menjaga dan memelihara kedamaian di tengah masyarakat yang plural.

Secara umum dapat digambarkan bahwa sikap inklusif adalah membiarkan orang lain memiliki pendapat yang berbeda dengan pendapatnya, atau melakukan hal yang tidak sesuai dengan pendapatnya, tanpa diganggu ataupun diintimidasi. Sikap inklusif adalah pemberian kebebasan kepada sesama manusia atau sesama warga masyarakat menjalankan keyakinannya, mengatur hidupnya dan menentukan nasibnya masing-masing, selama menjalankan dan menentukan sikapnya tidak melanggar dan tidak bertentangan dengan syarat-syarat azas terciptanya ketertiban dan kedamaian dalam masyarakat. Sikap inklusif diperlukan karena manusia tidak bisa hidup sendiri, manusia merupakan makhluk sosial dan selalu memerlukan kehadiran serta bantuan orang lain. Sikap inklusif merupakan modal utama untuk saling tolong menolong dan kerjasama di berbagai bidang kehidupan baik secara pribadi maupun kelompok.

Kemajemukan, pada dasarnya merupakan perwujudan dari kehendak Allah, Allah tidak menginginkan hanya ada satu agama meskipun sebenarnya Allah punya kemampuan untuk menjadikan umat yang satu bila Ia menghendakinnya. Seperti firman Allah: Jikalau Tuhanmu menghendaki, tentu dia menjadikan manusia umat yang satu (Qs. Hud: 118). Dalam mewujudkan kemaslahatan umum, agama telah menggariskan dua pola dasar hubungan yang harus dilaksanakan pemeluknya, yaitu hubungan vertikal dan hubungan horizontal. Hubungan vertikal adalah hubungan antara pribadi dengan al-khaliq yang direalisasikan dalam bentuk ibadah formal. Toleransi hubungan vertikal ini hanya terbatas pada intern suatu agama saja (Aulisa, 2016).

Adapun hubungan horizontal adalah hubungan manusia dengan sesamanya dan tidak hanya terbatas pada lingkungan agama tertentu, tidak pula pada orang yang seagama, melainkan berlaku secara umum dalam lingkup kerja sama kemasyarakatan demi kemaslahatan umum. Pada dasarnya meskipun masing-masing pengampu materi keagamaan mempunyai cara mengajar yang berbeda, tetapi materi agama yang diajarkan sebisa mungkin tidak menimbulkan sussa yang keruh antar peserta didik yang memiliki keyakinan berbedabeda. Bahkan bila di antara mereka ingin mengikuti pelajaran Pendidikan Agama Islam dan Budi Pekerti tetap diperbolehkan, dan bila mereka tidak ingin mengikutinya tidak dipermasalahkan, hanya saja mereka tidak melepasnya begitu saja, melainkan mereka diarahkan agar melakukan kegiatan-kegiatan yang bermanfaat, agar waktu yang ada tidak disia-siakan begitu saja.

Salah satu peserta didik yang beragama Kristen, Krisna mengakui, bahwa dia tidak pernah punya masalah dengan peserta didik yang berbeda keyakinan maupun dengan pengajar PAI. Selama ini dia mudah memahami materi yang diajarkan oleh pengajar PAI. Ada nilai-nilai 
yang kaku seperti halnya juga ada dalam agama yang dipeluknya. Tetapi ada juga nilai-nilai yang bersifat universal, seperti dalam kehidupan sosial yang harus dihormati bersama.

Dapat digambarkan bahwa peserta didik di SMAN 3 diberikan fasilitas untuk meperdalam, mengamalkan dan menjalankan perintah agamanya masing-masing. Setiap pendidik dan peserta didik bisa saling menjaga kondisi yang harmonis dan saling mendukung. Para pendidik bersatu membina, mendidik, membimbing serta mengarahkan peserta didik agar kelak mereka menjadi manusia yang berguna bagi bangsa. Suasana belajar yang kondusif, ditunjang dengan sejumlah peraturan, memungkinkan setiap peserta didik sangat menghormati para pendidik.

\section{KESIMPULAN}

$B^{\prime}$ Religi adalah satu kegiatan keagamaan yang bisa menjadi alternatif pilihan dalam menanamkan nilai-nilai inklusif di SMAN 3 Malang. Program ini untuk menjembatani minimnya pembelajaran agama di ruang kelas yang berorientasi pada sikap inkulsif. Pada penyelenggaraan B'Religi, melalui acara do'a bersama dan aktvitas keagamaan yang saling mendukung, peserta didik diajak berinteraksi dan memahami nilai-nilai/ajaran agama, memahami kultur dan nilai-nilai agama lain yang menjadi keyakinan peserta didik.

Pada penyelenggaraan B'Religi peserta didik menjadi bagian dari aktor yang bebas berkreativitas. Artinya mereka tidak hanya sebagai peserta melainkan juga menjadi bagian vital dari penyelenggaraan kegiatan yang berbasis inklusivisme tersebut. Sementara pendidik berperan sebagai pendamping. Dengan desain kegiatan keagamaan yang seperti ini, peserta didik dapat belajar memecahkan masalah, berempati, saling memahami dan menghargai peserta didik yang berbeda keyakinan.

Kegiatan B'Religi ini perlu menjadi teladan bagi sekolah-sekolah lainnya, karena muatan pendidikan sikap inklusif pada kegiatan ini relevan dengan tuntutan kurikulum. Desain kegiatannya pun dirancang untuk memberikan pengaruh yang sangat baik pada peserta didik, sekaligus memberikan pengalaman nyata tentang sikap inklusif antar pemeluk agama berbeda. Sebab itu, pengambil kebijakan perlu untuk terus meningkatkan pembinaan sikap inklusif bagi anak bangsa guna mengantisipasi ekses negatif dari kehidupan global. Sebagai tambahan, penting juga untuk menyelamatkan generasi masa depan tersebut, maka penting mendesakkan kurikulum pendidikan yang berbasiskan multikulturalisme/inklusivisme (Nafik Muthohirin, 2019).

Selama ini, di ruang-ruang kelas, memang telah ada muatan materi yang mengenalkan tentang keberagaman melalui Pendidikan Pancasila dan Kewarganegaraan (PPKN), namun implementasinya masih sebatas wacana yang tetap memunculkan sikap toleransi yang masih pasif. B'Religi adalah satu konsep pendidikan multikultural, di mana peserta didik dikenalkan tentang urgensi perbedaan lebih dari sekedar menghafal dan mempelajarinya melalui buku ajar, tapi praktik dan keteladanan dari seluruh stakeholder di sekolah sangat penting untuk mereka adopsi. 


\section{DAFTAR PUSTAKA}

Abadi, M., \& Muthohirin, N. (2020). Metode Cultural Responsive Teaching dalam Pendidikan Agama Islam: Studi Kasus Tindak Xenophobia dan Rasisme di Tengah Bencana Covid19. Progresiva: Jurnal Pemikiran Dan Pendidikan Islam, 9(1), 34-48.

Aulisa, E. S. N. (2016). Islamic Character Building, Membangun Insan Kamil, Cendikia Berakhlak Qur'ani. Jurnal Sosioteknologi, 15(3), 412-415.

Azali, K. (2017). Fake news and increased persecution in Indonesia. IYI Institute (Ed.), 61.

Bawazir, T. (2015). Jalan tengah demokrasi: antara fundamentalisme dan sekularisme. Pustaka Al Kautsar.

Burhani, A. N. (2019). Menemani Minoritas: paradigma Islam tentang keberpihakan dan pembelaan kepada yang lemah. PT. Gramedia Pustaka Utama.

Fernandes, R. (2018). Adaptasi Sekolah Terhadap Kebijakan Pendidikan Inklusif. SOCIUS, 4(2), 119-125.

Ghufron, A. (2010). Integrasi nilai-nilai karakter bangsa pada kegiatan pembelajaran. Jurnal Cakrawala Pendidikan, 1(3).

Ghufron, G. (2020). Relasi Islam-Kristen: Studi Kasus di Desa Tegalombo, Pati, Jawa Tengah. Progresiva: Jurnal Pemikiran Dan Pendidikan Islam, 9(1), 1-25.

John, W. C. (2014). Penelitian Kualitatif dan Desain Riset, Memilih diantara Lima Pendekatan. Yogyakarta: Pustaka Pelajar.

Lim, M. (2017). Freedom to hate: social media, algorithmic enclaves, and the rise of tribal nationalism in Indonesia. Critical Asian Studies, 49(3), 411-427.

Mahfud, C. (2006). Pendidikan multikultural. Pustaka Pelajar.

Muaddab, H. (2020). Diskursus Minoritas Melalui Kurikulum, Buku dan Kultur di Sekolah. Progresiva: Jurnal Pemikiran Dan Pendidikan Islam, 9(1), 49-61.

Muhaimin. (2005). Pengembangan kurikulum pendidikan agama Islam: di sekolah, madrasah, dan perguruan tinggi. RajaGrafindo Persada.

Muthohirin, Nafi'. (2014). Fundamentalisme Islam; Gerakan dan Tipologi Pemikiran Aktivis Dakwah Kampus. Jakarta: IndoStrategi.

Muthohirin, Nafi. (2015). Radikalisme Islam dan pergerakannya di media sosial. Afkaruna: Indonesian Interdisciplinary Journal of Islamic Studies, 11(2), 240-259.

Muthohirin, Nafik. (2019). Politik Identitas Islam dan Urgensi Pendidikan Multikultural. J-PAI: Jurnal Pendidikan Agama Islam, 6(1).

Nasional, K. P. (2010). Pengembangan Budaya dan Karakter Bangsa: Pedoman Sekolah. Jakarta: Puskur Balitbang Kemendiknas.

Nurcholish, D. (2020). Implementasi Manajemen Pendidikan Multikultural di SMP Tumbuh Yogyakarta. Progresiva: Jurnal Pemikiran Dan Pendidikan Islam, 8(2), 83-91.

Syam, N. (2018). Demi Agama, Nusa, dan Bangsa: Memaknai Agama, Kerukunan Umat Beragama, Pendidikan, dan Wawasan Kebangsaan. 